\title{
THE EFFECT OF HEALTH EDUCATION TOWARD KNOWLEDGE OF THE ELDERLY IN MANAGEMENT RISK OF URINARY INCONTINENCE
}

\author{
Tina Yuli Fatmawati ${ }^{1)}$, Agustina ${ }^{2)}$ \\ 1),2) Sekolah Tinggi Ilmu Kesehatan Baiturrahim Jambi \\ Email:tinayulifatmawati@yahoo.com
}

\begin{abstract}
Indonesia as one of the countries in Asia is a country that experienced an increase in the elderly population rapidly. Survey in 11 Asian countries including Indonesia found 5,052 women suffering from urinary incontinence problems. Along with increasing age, the ability to hold urine is decreasing, so that the elderly have the potential to experience urinary incontinence so intervention is needed to deal with this problem. The purpose of this study was to determine the effect of health education on elderly knowledge in the management of the risk of urinary incontinence. This research is a quantitative research using the One Group pretest-posttest design. The research was conducted at the Posyandu Kasih in the capital city of Jambi. Sampling technique is accidental sampling, with a sample of 20 respondents, data analysis using univariate and bivariate with $T$ dependen The result of this research that knowledge of the elderly before health education the highest value is 9 , the lowest score was 4 with an average overall score of elderly is 6.30. After health education the highest value is 14 and the lowest was 10 with an average overall score of elderly is 12.05. there was an effect of health education on elderly knowledge in the risk management of urinary incontinence in Posyandu Kasih Ibu.
\end{abstract}

Keywords: Health education, Knowledge, Incontinence, elderly

\begin{abstract}
ABSTRAK
Survei di 11 negara Asia termasuk Indonesia ditemukan 5.052 perempuan menderita masalah inkontinensia urin. Seiring dengan bertambahnya usia, kemampuan menahan kencing ini semakin menurun, sehingga lanjut usia berpotensi untuk mengalami inkontinensia urin sehingga dibutuhkan intervensi untuk menangani masalah ini. Tujuan penelitian ini untuk mengetahui Pengaruh Pendidikan Kesehatan Terhadap Pengetahuan Lansia Dalam Penatalaksanaan Risiko Terjadinya Inkontinensia Urin. Penelitian ini merupakan penelitian kuantitatif dengan menggunakan rancangan One Group pretestposttest. Penelitian dilakukan di Posyandu Kasih Ibu Kota Jambi. Teknik pengambilan sampel accidental sampling, dengan jumlah sampel 20 responden, Analisis data menggunakan univariat dan bivariat dengan uji statistik $T$ dependent. Hasil penelitian menunjukkan, pengetahuan lansia sebelum dilakukan pendidikan kesehatan skor tertinggi adalah 9, skor terendah adalah 4 dengan rata-rata nilai 6.30. Setelah dilakukan pendidikan kesehatan skor tertinggi adalah 14 dan terendah adalah 10 dengan rata-rata nilai 12.05. Secara statistik ada pengaruh pendidikan kesehatan terhadap pengetahuan lansia dalam penatalaksanaan risiko terjadinya inkontinensia urin di Posyandu Kasih Ibu.
\end{abstract}

Kata kunci : Pendidikan kesehatan, Pengetahuan, Inkontinensia Urin, Lansia. 


\section{PENDAHULUAN}

Inkontinensia urin masih dianggap suatu yang tabu untuk di bicarakan atau di akui oleh masyarakat. Inkontinensia urin dapat menyebabkan masyarakat membatasi aktivitas sosial dan kemasyarakatan, sehingga dibutuhkan intervesi suatu pengetahuan dan pencegahan untuk penanganan inkontinensia urin. ${ }^{1}$

Fenomena di dunia, diperkirakan sekitar $20 \%$ perempuan mengalami inkontinensia urin. Menurut departemen pelayanan manusia dan kesehatan Amerika serikat menyatakan jumlah penduduk yang mengalami inkontinensia urin mencapai 13 juta orang dengan rincian angka populasi penduduk yang berusia 15-64 tahun dan 10\% $30 \%$ penderita wanita dan $1,5 \%-5 \%$ penderita pria.

Survei di 11 negara Asia termasuk Indonesia ditemukan 5.052 perempuan menderita masalah inkontinensia urin. Indonesia sebagai salah satu negara di Asia merupakan negara yang mengalami peningkatan penduduk lansia yang sangat pesat. Pada tahun 1971, penduduk lanjut usia (lansia) berjumlah 5,3 juta atau $4,48 \%$ dan pada tahun 1990 meningkat menjadi 12,7 juta $(6,56 \%)$. Sejak tahun 2002, proporsi penduduk lansia di Indonesia telah mencapai di atas 7\%. Pada 2010, jumlah lansia $9,58 \%$ dengan usia harapan hidup 67,4 tahun. Pada tahun 2020, angka tersebut meningkat menjadi $11,20 \%$ dengan usia harapan hidup rerata 70,1 tahun. Jumlah ini berarti meningkat 3 kali lipat jika dibandingkan dengan jumlah lansia pada tahun 1990. Jumlah lansia saat ini, seperti diinformasikan oleh Badan Pusat Statistik (BPS), adalah 14.439.967 orang atau $7,18 \%$ dengan usia harapan hidup rerata 64,5 tahun. Sebagian di antara mereka terlantar, mengalami penyakit menahun, tindakan kekerasan, dan perlakuan salah. $^{2}$

Di Indonesia sendiri sekitar $5,8 \%$ penduduk menderita inkontinensia urin. Pada tahun 1950, di Asia terdapat 55 juta laki-laki dan perempuan yang berusia $65 \mathrm{ke}$ atas. Sedangkan pada tahun 2000, jumlahnya meningkat menjadi 207 juta dan menurut proyeksi jumlah tersebut akan meningkat lagi pada tahun 2050 menjadi 865 juta orang atau sekitar $20 \%$ dari penduduk dewasa . ${ }^{3}$

Data dari Dinkes Kota Jambi di 20 puskesmas Kota Jambi pada tahun 2014 jumlah kunjungan lansia perempuan berdasarkan umur dengan jumlah 53319 orang. Dari data 20 puskesmas tersebut bahwa Puskesmas Putri Ayu Kota Jambi memegang urutan pertama terbanyak. Dengan diketahui jumlah lansia di Puskesmas Putri Ayu pada tahun 2014 yang berumur 45-59 tahun sebanyak 5498, umur 60-69 tahun sebanyak 2833 dan umur $>70$ tahun sebanyak 1450 .

Seiring dengan bertambahnya usia, kemampuan menahan kencing ini semakin menurun, sehingga lanjut usia berpotensi untuk mengalami kencing yang tidak terasa atau "mengompol". Kencing yang tidak terasa ini akan sangat mempengaruhi baik secara fisik maupun psikologis lanjut usia. ${ }^{4}$ Keluhan desakan berkemih dan sering berkemih kerap terjadi karena pertambahan usia. Pada pria, perubahan ini sering kali 
terjadi karena pembesaran prostat dan pada wanita terjadi kerena kelemahan otot yang menyokong kandung kemih atau kelemahan sfingter uretra. Panjang uretra pada wanita sekitar $3,7 \mathrm{~cm}$ sedangkan pada pria panjangnya sekitar $20 \mathrm{~cm}$. Pada pria dan wanita, uretra memiliki lapisan membran mukosa yang bersambungan dengan kandung kemih dan ureter. Dengan demikian, infeksi uretra dapat meluas dari saluran kemih keginjal. Wanita terutama rentan terkena infeksi saluran kemih karena uretra mereka yang pendek dan karena kedekatan meatus urinarius ke vagina dan anus yang merupakan faktor risiko inkontinensia urin. $^{5}$

Inkontinensia memiliki implikasi medis, psikologis, sosial, dan ekonomis. Dari segi medis, inkontinensia mempermudah timbulnya ulkus dekubitus, infeksi saluran kemih, sepsis, gagal ginjal, dan peningkatan angka kematian. Implikasi psikologis-sosial antara lain kurang percaya diri, hambatan pergaulan, dan aktivitas seksual, depresi dan ketergantungan pada orang lain. Penyakit ini merupakan salah satu faktor utama yang membuat banyak keluarga menempatkan manula tersebut di panti jompo untuk mendapatkan perawatan yang layak. Biaya untuk perawatan di panti atau rumah sakit merupakan implikasi ekonomis yang sangat bervariasi. ${ }^{2}$

Pendidikan kesehatan adalah suatu komponen keperawatan gerontologi yang esensial. Fokus dan tujuan pendidikan kesehatan adalah untuk menggambarkan masalah, menyarankan perilaku koping, dan memfasilitasi penguasaan dan pengendalian klien. Bagi lansia, pendidikan kesehatan ini mungkin untuk membantu orang yang mengalami penyakit kronis dalam beradaptasi terhadap penyakitnya, menghadapi masalah, dan memahami proses yang berhubungan dengan penuaan. Hal ini juga berarti untuk membantu lansia mempertahankan kesehatan yang baik dan berfungsi mandiri serta hidup yang lebih panjang, hidup lebih sehat. Pendidikan klinis pada lansia dikenal dapat meningkatkan pengetahuan mereka. Lansia sangat sedikit yang telah menyelesaikan pendidikan dari sekolah menengah atas (sekitar 49\%) daripada keseluruhan populasi yang berusia 25 tahun keatas (75\%). Sedikitnya 1 dari 5 orang lansia dalam populasi di Amerika Serikat yang bukan kulit putih yang telah lulus dari sekolah menengah umum, kebanyakan mempunyai pendidikan tidak lebih dari pendidikan sekolah dasar. $^{6}$

Hal ini menunjukkan, kurangnya pengetahuan tentang masalah kesehatan terutama pada penanganan inkontinensia urin. Penatalaksanaan yang selama ini sering dilakukan pada lansia dengan inkontinensia urin adalah memasang kateter secara menetap disertai dengan melakukan kegiatan latihan berkemih (bladder training). Namun, tidak jarang, sering pemasangan kateter mengundang risiko untuk terjadinya komplikasi yaitu terjadi infeksi saluran kemih. Disisi lain, upaya untuk mengatasi inkontinensia urin dilakukan melalui pemberian obat-obatan untuk merelaksasikan otot kandung kemih yang justru dapat mencetuskan terjadinya retensi urin. Upaya lain yaitu latihan dasar 
panggul latihan ini sangat membantu bagi wanita yang fungsi kognitifnya utuh yang mengalami inkontinensia urin, sedangkan pembalut inkontinens (popok) digunakan hanya sebagai upaya terakhir. Pembalut inkontinensia sangat berguna pada waktu pasien mengalami inkontinensia stres atau total untuk melindungi pakaian, tetapi penggunanya harus dihindari bilamana memungkinkan. Pembalut ini harus menjauhkan kelembaban dari tubuh untuk meminimalkan kontak lembab dan ekstreta dengan baik. $^{7}$

Survey awal yang dilakukan di Posyandu Kasih Ibu wilayah kerja Puskesmas Putri Ayu, dengan mewawancarai 10 orang Lansia. Didapatkan bahwa 6 orang lansia mengatakan sering kencing baik tidak atau ketika aktivitas fisik, batuk, atau bersin dan tidak mengetahui tentang kencing tidak terkontrol maupun penanganannya, 3 orang lansia mengatakan kadangkadang mengeluarkan kencing ketika aktivitas fisik, batuk, atau bersin dan tidak tahu tentang kencing tidak terkontrol maupun penanganannya, 1 orang lansia mengatakan tidak ada keluhan kencing tidak terkontrol dan tahu penanganannya seperti latihan kegel.

Berdasarkan yang telah uraian diatas maka peneliti tertarik untuk melakukan penelitian tentang, "Pengaruh Pendidikan Kesehatan Terhadap Pengetahuan Lansia Dalam Penatalaksanaan Risiko Terjadinya Inkontinensia Urin di Posyandu Kasih Ibu Kota Jambi Tahun 2016".

\section{METODE PENELITIAN}

Penelitian ini merupakan penelitian kuantitatif dengan desain pre experiment, dengan rancangan one group pre-test dan post-test yaitu penelitian yang dilakukan untuk mengetahui apakah ada pengaruh setelah dilakukan perlakuan. Tujuan penelitian ini untuk mengetahui Pengaruh Pendidikan Kesehatan Terhadap Pengetahuan Lansia Dalam Penatalaksanaan Risiko Terjadinya Inkontinensia Urin

Populasi penelitian ini sebanyak 80 lansia perempuan yang ada di wilayah kerja puskesmas Putri Ayu Kota Jambi. Teknik pengambilan sampel dalam penelitian ini menggunakan accidental sampling. Accidental sampling adalah penelitian yang dilakukan dengan mengambil responden yang kebetulan ada atau tersedia di suatu tempat sesuai dengan konteks penelitian. Pengambilan sampel untuk penelitian eksperimen yang sederhana jumlah anggota sampel masing-masing 10 sampai dengan 20. ${ }^{8}$ Dengan menggunakan kaidah diatas maka besar sampel dalam penelitian ini sebanyak 20 orang. Instrumen penelitian yang digunakan dalam penelitian ini adalah kuesioner. Analisis data menggunakan uji statistik $T$ dependent.

HASIL DAN PEMBAHASAN

$\begin{array}{ll}\text { Tabel } & \begin{array}{l}\text { 1. Distribusi frekuensi } \\ \text { responden berdasarkan } \\ \text { Usia }\end{array}\end{array}$ 


\begin{tabular}{cccc}
\hline No & Umur & Frekuensi & $(\%)$ \\
\hline $\mathbf{1}$ & $\begin{array}{c}45-49 \\
\text { tahun }\end{array}$ & 10 & $50 \%$ \\
$\mathbf{2}$ & $\begin{array}{c}50-59 \\
\text { tahun }\end{array}$ & 8 & $40 \%$ \\
$\mathbf{3}$ & $\begin{array}{c}60 \\
\text { tahun }\end{array}$ & 2 & $10 \%$ \\
\hline Jumlah & 20 & $100 \%$ \\
\hline
\end{tabular}

Berdasarkan tabel 1 diketahui bahwa usia responden terbanyak adalah usia 45-49 tahun dengan jumlah 10 responden $(50 \%)$ dan usia 60 tahun merupakan usia responden yang paling sedikit dengan jumlah 2 responden (10\%).

Hasil penelitian didapatkan perbedaan proporsi usia pada responden 45- 49 tahun dengan presentase 50\%, usia 50-59 tahun dengan $40 \%$ dan 60 tahun $10 \%$. Hal ini, menunjukkan bahwa semua responden berada pada rentang usia pra lansia atau lansia usia pertengahan.

Usia dapat mempengaruhi terjadinya inkontinensia urin, karena jika dilihat dari aspek fisik semakin bertambahnya usia maka seseorang akan mengalami berbagai perubahan fisiologis pada setiap organ khususnya pada system perkemihan. Sehingga dapat disimpulkan bahwa seseorang yang bertambahnya usia maka akan mengalami perubahan fisik maupun fisiologi khususnya terjadinya inkontinensia urin.

\section{Tabel 2. Distribusi frekuensi responden berdasarkan jenjang Pendidikan}

\begin{tabular}{|c|c|c|c|}
\hline No & $\begin{array}{c}\text { Jenjang } \\
\text { Pendidikan }\end{array}$ & Frekuensi & $(\%)$ \\
\hline 1 & $\begin{array}{c}\text { Tidak } \\
\text { Sekolah }\end{array}$ & 6 & $30 \%$ \\
\hline 2 & SD & 7 & $35 \%$ \\
\hline 3 & SMP & 2 & $10 \%$ \\
\hline 4 & SMA & 3 & $15 \%$ \\
\hline 5 & $\begin{array}{c}\text { Perguruan } \\
\text { Tinggi }\end{array}$ & 2 & $10 \%$ \\
\hline & Total & 20 & $100 \%$ \\
\hline
\end{tabular}

Berdasarkan tabel 2 diketahui bahwa jenjang pendidikan SD merupakan yang terbanyak dengan jumlah 7 responden (35\%) dan Perguruan Tinggi merupakan jenjang pendidikan yang paling sedikit dengan jumlah 2 responden (10\%).

Pendidikan berarti bimbingan yang diberikan seseorang pada orang lain terhadap sesuatu hal agar mereka dapat memahami. Makin tinggi pendidikan seseorang semakin mudah pula mereka menerima informasi dan pada akhirnya makin banyak pula pengetahuan yang dimilikinya. Sebaliknya jika seseorang tingkat pendidikannya rendah, akan menghambat perkembangan sikap seseorang terhadap penerimaan, informasi dan nilai-nilai yang baru diperkenalkan. ${ }^{9}$ Hasil dari penelitian didapatkan bahwa frekuensi terbanyak dari jenjang pendidikan responden adalah sekolah dasar sebesar 35\% dan tidak sekolah sebesar $30 \%$. Hal ini, menunjukkan masih rendahnya responden yang belum mendapat pendidikan tinggi disekolah. Sehingga dapat disimpulkan, pendidikan yang tinggi sangat menentukan kemampuan seseorang dalam memanfaatkan pengetahuan dalam masalah kesehatan yang dihadapinya khususnya inkontinensia urin. 
Tabel 3. Distribusi frekuensi responden berdasarkan pekerjaan di Posyandu

\begin{tabular}{cccc}
\hline No & $\begin{array}{c}\text { Jenjang } \\
\text { Pekerjaan }\end{array}$ & Frekuensi & $(\%)$ \\
\hline 1 & IRT & 11 & $55 \%$ \\
2 & Dagang & 7 & $35 \%$ \\
3 & Guru & 2 & $10 \%$ \\
& Total & 20 & 100 \\
& & & $\%$ \\
\hline
\end{tabular}

Berdasarkan tabel 3 diketahui bahwa pekerjaan IRT merupakan yang terbanyak dengan jumlah 11 responden $(55 \%)$ dan dagang merupakan jenjang pendidikan yang paling sedikit dengan jumlah 2 responden (10\%).

Pekerjaan adalah serangkaian tugas atau kegiatan yang harus dilaksanakan atau diselesaikan oleh seseorang sesuai dengan jabatan atau pfofesi masing-masing. Status pekerjaan yang rendah sering mempengaruhi tingkat pengetahuan seseorang. Pekerjaan biasanya sebagai symbol status social di masyarakat. ${ }^{10}$

Hasil dari penelitian
didapatkan bahwa terbanyak adalah ibu rumah tangga (IRT) sebanyak $55 \%$ dan Guru sebanyak $10 \%$. Hal ini, menunjukkan bahwa masih banyaknya penduduk yang tidak bekerja dikarenakan kurangnya mendapat pendidikan yang tinggi disekolah. Sehingga dapat disimpulkan pengetahuan seseorang dalam penguasaan ilmu yang dimilikinya dapat terkait oleh pekerjaannya.

Tabel 4. Pengaruh Pendidikan Kesehatan Terhadap Pengetahuan Lansia Dalam Penatalaksanaan Risiko Terjadinya Inkontinensia Urin

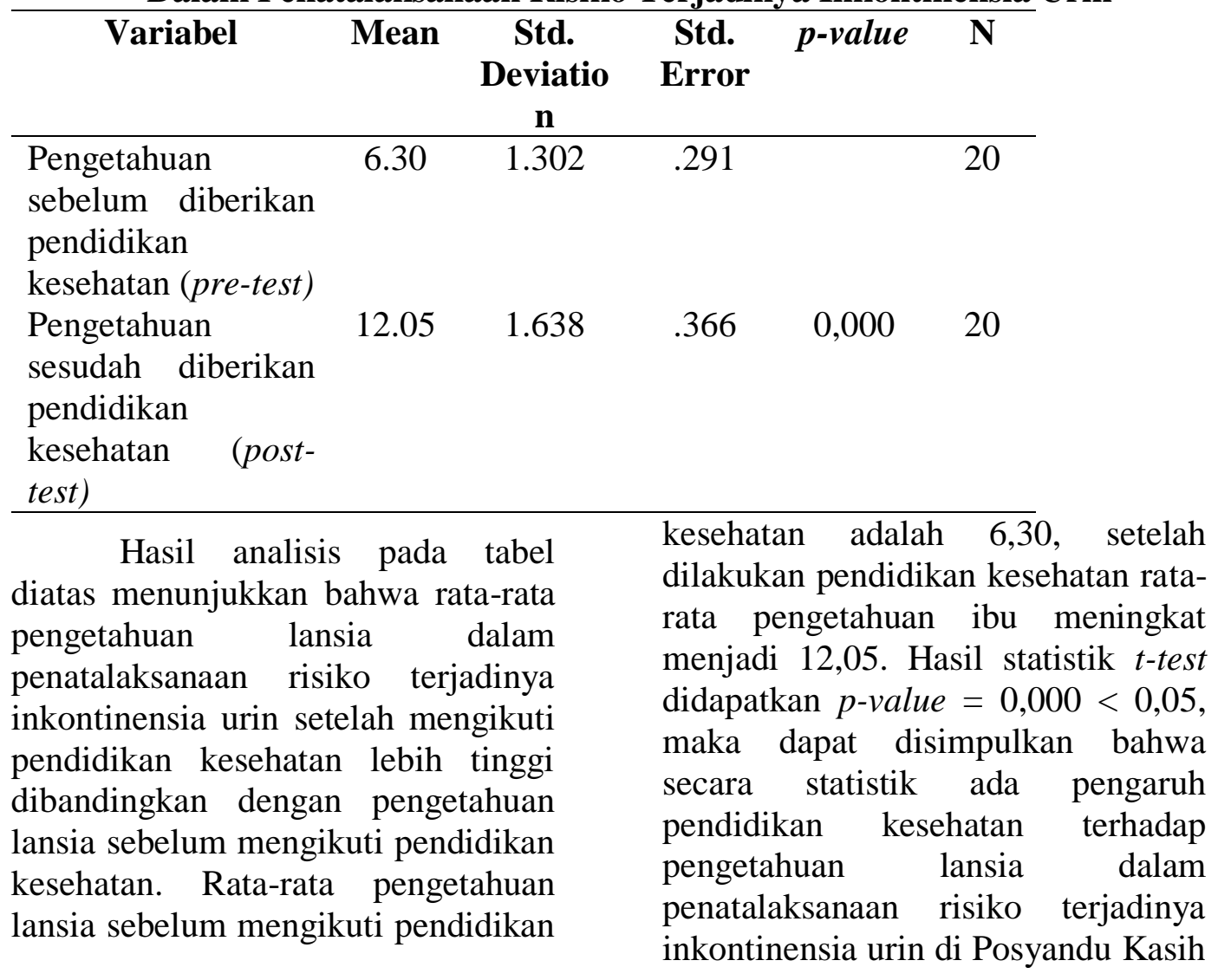


Ibu Kota Jambi, yang berarti pengetahuan responden mengalami perubahan positif setelah diberikan pendidikan kesehatan.

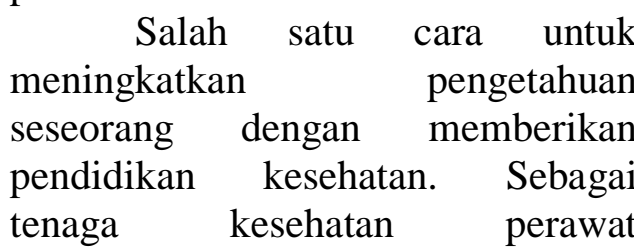
mempunyai peran yang sangat penting dalam memelihara dan meningkatkan kesejahteraan masyarakat. dengan demikian, peran perawat sebagai pendidik sangat berperan dalam usaha meningkatkan pengetahuan dengan pendidikan kesehatan. $^{11}$

Hasil penelitian ini sejalan dengan penelitian yang dilakukan oleh Angellita Intan (2012), Latihan Kegel dengan Penurunan Gejala Inkontinensia Urin Pada Lansia. Hasil dari penelitian ini menunjukkan bahwa latihan kegel efektif terhadap penurunan gejala inkontinensia urin pada lansia. dengan demikian, perawat dapat mengajarkan latihan kegel sebagai intervensi nonfarmakologis untuk mengatasi inkontinensia urin. ${ }^{12}$

Hasil penelitian yang dilakukan oleh Della Sari (2012), Pengaruh Kegel Exercise dan Electrical Stimulation Terhadap Incontinencia Urine Pada Lanjut Usia. Hasil dari penelitian ini uji pengaruh antara kelompok perlakuan dan kontrol sebesar 0,170, sehingga tidak signifikan, artinya tidak ada pengaruh pemberian kegel exercise dan electrical stimulation terhadap incontinencia urine pada usia lanjut, sedangkan pada kelompok perlakuan diperoleh nilai $p \_v a l u e$ sebesar 0,001 sehingga dikatakan signifikan artinya adanya pengaruh pemberian kegel exercise dan electrical stimulation terhadap incontinencia urine pada usia lanjut. ${ }^{13}$

Dari hasil penelitian setelah dilakukan pendidikan kesehatan pengetahuan responden mengalami peningkatan dari yang tidak tahu menjadi tahu. Hasil penelitian ini menyatakan bahwa pendidikan kesehatan dapat digunakan sebagai upaya peningkatan pengetahuan lansia tentang risiko terjadinya inkontinensia urin.

\section{SIMPULAN}

1. Nilai rata-rata pengetahuan lansia dengan penatalaksanaan risiko terjadinya inkontinensia urin sebelum mengikuti pendidikan kesehatan yaitu rata-rata 6.30 dengan hasil rendah dan Standar devisiasi 1.302.

2. Nilai rata-rata pengetahuan lansia dengan penatalaksanaan risiko terjadinya inkontinensia urin setelah mengikuti pendidikan kesehatan yaitu rata-rata 12.05 dengan hasil tinggi dan Standar devisiasi 1.638.

3. Ada pengaruh pendidikan kesehatan terhadap pengetahuan lansia dalam penatalaksanaan risiko terjadinya inkontinensia urin di Posyandu Kasih Ibu Kota Jambi dari mean 6.30 menjadi mean 12.05 .

\section{SARAN}

Untuk peneliti selanjutnya agar dapat melakukan penelitian lanjutan tentang Inkontinensia urine dengan variabel dan metode yang berbeda. Bagi Pihak Puskesmas 
dapat lebih sering melakukan penyuluhan kesehatan kepada lansia khususnya tentang Inkontinensia Urien di Posyandu Lansia.

\section{DAFTAR PUSTAKA}

1. Walidatul. 2013. Hubungan Pengetahuan Perawat Tentang Inkontinensia Urin Terhadap Praktik Keperawatan Inkontinensia Urin di RSU Kabupaten Tanggerang. Skripsi. Universitas Islam Negeri Syarif Hidayatullah, Jakarta

2. Azwar. 2010. Penyakit diusia Tua. EGC. Jakarta

3. Rusyda Ulya. 2010. Hubungan Antara Tingkat Pengetahuan Keluarga Tentang Kegel Training Dengan Praktik Pelaksanaan Kegel Training Pada Lansia Yang Mengalami Inkontinensia Urin. Jurnal. Stikes Muhammadiyah Kudus

4. Rustanti, Marti dkk. 2015. Pengaruh Latihan Otot Dasar Panggul Pada Perempuan Lanjut Usia Dengan Gangguan Inkontinensia Urin. Jurnal. Kemenkes Politeknik Kesehatan. Surakarta.

5. Kozier. 2010. Buku Ajar Fundaental Keperawatan: Konsep, Proses, \& Praktik, Edisi 7. EGC. Jakarta

6. Stanley, $\mathbf{M}$ and Patricia, G.B. 2007. Gerontologi Nursing: a health promotion/protection approach, $2^{\text {nd }}$ ed. Nety J. Sari K, Alih Bahasa. Buku Ajar Keperawatan Gerontik, Edisi 2. EGC. Jakarta
7. Smeltzer, Suzanne C. 2001. Buku Ajar Keperawatan Medikal-Bedah Brunner \& Suddarth. Edisi 8. EGC. Jakarta

8. Sugiyono. 2012. Statistik Untuk Penelitian. Alfabeta. Bandung

9. Mubarak, dkk. 2007. Promosi Kesehatan : Sebuah Pengantar Proses Belajar Mengajar. Graha Ilmu. Yogyakarta

10. Notoatmodjo. 2012. Metodologi penelitian kesehatan. Rineka Cipta. Jakarta

11. Suliha, U dkk. 2005. Pendidikan Kesehatan dalam Keperawatan. EGC. Jakarta

12. Angellita Intan. 2012. Latihan Kegel Dengan Penurunan Gejala Inkontinensia Urin Pada Lansia. Jurnal. Universitas Sumatera Utara

13. Della Sari.2012. Pengaruh Kegel Exercise dan Electrical Stimulation Terhadap Incontinencia Urine Pada Lanjut Usia.Jurnal. Univ Muhammadiyah. Surakarta 